\title{
САНІТАРНО-ЕПІДЕМІЧНА І ГУМАНІТАРНА ДІЯЛЬНІСТЬ ЧЕРВОНОГО ХРЕСТА У СХІДНІЙ ГАЛИЧИНІ ПЕРІОДУ ЗУНР У КОНТЕКСТІ БЛАГОДІЙНОЇ АКТИВНОСТІ МІСЦЕВОГО НАСЕЛЕННЯ
}

\author{
Олег ОЛІЙнИк \\ Державний вищий навчальний заклад \\ "Прикарпатський національний університет імені Василя Стефаника", \\ кафедра всесвітньої історії, \\ вул. Шевченка, 57, 76018, Івано-Франківськ, Україна \\ e-mail:oleg93hist@meta.ua \\ DOI: $10.15330 /$ gal.32.74-82 \\ ORCID: 0000-0001-5612-7236
}

\begin{abstract}
Проаналізовано організаційну структуру та санітарно-епідемічну $і$ гуманітарну діяльність Українського Червоного Хреста на теренах Галичини. Розглянуто історичні умови, в яких праиювала дана організація. Звернуто увагу на складне медичне та гуманітарне становище краю, спричинене тривалими військовими діями періоду Першої світової війни та наростаючим польсько-украӥнським конфліктом, що зумовили потребу створення та організаиійного оформлення Українського Червоного Хреста. Проаналізовано ставлення та участь у роботі організації представників медичної спільноти різних національностей Східної Галичини. Висвітлено роботу іноземних місій червонохресних структур на території краю та їх взаємодію з місиевою владою. Розглянуто процес взаємодї̈ Польського та Українського товариств Червоного Хреста у вирішенні проблеми опіки над полоненими та інтернованими вояками в процесі переміщення цивільних осіб через лінію фронту. Охарактеризовано вплив та масштаби благодійної активності місиевого украӥнського та єврейського населення на роботу Українського Червоного Хреста.
\end{abstract}

Ключові слова: Червоний Хрест, Східна Галичина, ЗУНР, благодійна активність.

3 перших днів існування Західно-Української Народної Республіки (далі - ЗУНР) у Східній Галичині виникає потреба у медичній, санітарній та гуманітарній допомозі армії та цивільному населенню. Проте ситуація виявилася складною, зумовлена поширенням епідемій висипного тифу, який не був ліквідований, починаючи від зими 1915-1916 р. Міграція великої кількості силовиків, звільнених полонених, евакуйованих чи насильно виселених людей постійно "підгодовували" поширення черевного і поворотного тифу, віспи, завошивлення ${ }^{1}$. Крім того, польсько-український військовий конфлікт у Східній Галичині спричинив нагальну потребу у медичній допомозі. Саме таку роботу серед інших організацій, що функціонували на теренах ЗУНР, здійснював Червоний Хрест. Перед ним також гостро постала проблема санітарно-епідеміологічного забезпечення населення в місцевостях наближених до лінії фронту та організації належних умов утримання полонених та інтернованих військових ${ }^{2}$.

Дана проблема в українській історіографії досліджена не достатньо. У своїх працях їй приділяли увагу В. Трембіцький (“Санітарно-медична справа в Україні. Санітарно-червонохресна служба в Галицькій державі”) ${ }^{3}$ та С. Олеськів (“Причинки до історії Українського

\footnotetext{
${ }^{1}$ Кравець А. Медики у визвольних змаганнях українського народу : (від Українського Червоного Хреста до Служби Здоров’я УПА). Львів : Галицька видавнича спілка, 2010. С. 25.

${ }^{2}$ Олійник О. Діяльність Українського Червоного Хреста у Східній Галичині в період ЗУНР. Україна у світовому історичному простор : зб. матеріалів Всеукр. наук.-практ. конф. м. Маріуполь. 21 квітня 2017 р. / під заг. ред. К. В. Балабанова. Маріуполь : МДУ, 2017. С. 57-60.

${ }^{3}$ Трембіцький В. Санітарно-медична справа в Україні. Санітарно-червоно-хресна служба в Галицькій державі. Вісті комбатанта. 2016. 27 березня. URL: http://komb-a-ingwar.blogspot.com/2016/03/blogpost_27.html?m=1.
} 
Червоного Хреста на 3.У.3.” $)^{4}$. У низці праць, присвячених розвитку медицини в регіоні, дослідники опосередковано звертають увагу на діяльність Червоного Хреста. Слід виокремити статті Л. Давибіди “Боротьба з інфекційними захворюваннями в Західно-Українській Народній Республіці", О. Сапіги "Кадрове забезпечення медичної та санітарної служби УГА в 19181920 pp."”. Фрагментарно питання діяльності Червоного хреста у Східній Галичині в період ЗУНР у своїх роботах висвітлюють також А. Кравець - "Медики у визвольних змаганнях українського народу: (від Українського Червоного Хреста до Служби Здоров'я УПА)"7 та В. Рутар - "Мобілізаційне і матеріально-технічне забезпечення Галицької Армії в період українськопольської війни 1918-1919рр. (За матеріалами повітової преси ЗУНР)”8.

Вже на початковому етапі польсько-української війни, коли ще тільки розпочалось становлення структур Українського (Галицького) Червоного Хреста, дана організація зіткнулася зі значними труднощами у своїй діяльності ${ }^{9}$. Фактично, Галицький Червоний Хрест та його санітарні станиці самочинно творили у повітах місцеві українські лікарі та жіночі організації. Післяавстрійська медична червонохресна спадщина була невелика, бо ввесь лікарсько-медичний запас був сконцентрований переважно на фронтовій лінії (Балкани (Македонія, Албанія) та Альпи на італійському фронті). Лише дуже мала частина лікарського майна залишилася на т. зв. східному фронті, тобто на прикордонні з Наддніпрянською Україною, де від 1918 р. боїв вже майже не було ${ }^{10}$.

Значно ускладнювали надання медичної допомоги військовим і мирному населенню тривалі кровопролитні бої на вулицях м. Львова ${ }^{11}$. Військові дії вимагали створення баз оперативних відділів, де б знаходились перев'язочні точки, звідки санітари у відповідний час евакуювали поранених, виносили загиблих під безперервними обстрілами 3 вікон, дахів, пивниць будинків, які в цей час контролювались противником ${ }^{12}$. Негативний вплив на медичне забезпечення українських військ мав також національний чинник. Часто від походження лікаря залежало надання чи ненадання медичної допомоги ${ }^{13}$. Зокрема, санітарний поручник УГА Іван Рижій у своїх спогадах відзначав: “в Поліклініці при вул. Ліндого, що була для цивільних осіб, днем і ніччю оперував ранених вояків добровільно і безкорисно невролог проф. д-р Баронч, жид. (івський) Загальний шпиталь при вул. Гловінського обслуговував цивільних та рідко військових. Санаторія Червоного Хреста на Личакові була під управою Спілки Польських Лікарів, що відмовлялися подати поміч стрільцям"14. Тепер вся робота, відповідальність спала "на плечі” українських лікарів, тим більше, що майже всі лікарі-поляки покинули державну службу ${ }^{15}$. Це, у свою чергу, все гостріше ставило проблему організації роботи саме Українського Червоного Хреста в ЗУНР ${ }^{16}$.

\footnotetext{
${ }^{4}$ Олеськів С. Причинки до історії Українського Червоного Хреста на 3.У.З. Літопис Червоної Калини. Львів, 1934. Червень. С. 5-6. URL: http://avr.org.ua/index.php/viewDoc/11646/.

5 Давибіда Л. Боротьба з інфекційними захворюваннями в Західно-Українській Народній Республіці. Галичина. 2014. Ч. 25-26. С. 182-187.

${ }^{6}$ Сапіга О. П. Кадрове забезпечення медичної та санітарної служби УГА в 1918-1920 рр. Військовонауковий вісник. Академія сухопутних військ. Вип. 14. Львів, 2011. С. 93-107.

${ }^{7}$ Кравець А. Медики у визвольних змаганнях українського народу..

${ }^{8}$ Рутар В. С. Мобілізаційне і матеріально-технічне забезпечення Галицької армії в період українськопольської війни 1918-1919 рр. (за матеріалами повітової преси ЗУНР). Військово-науковий вісник. 2010. Вип. 14. С. 79-92. URL: http://nbuv.gov.ua/UJRN/vnv_2010_14_7.

${ }^{9}$ Олійник О. Діяльність Українського Червоного Хреста у Східній Галичині в період ЗУНР... С. 57-60.

${ }^{10}$ Трембіцький В. Санітарно-медична справа в Україні. Санітарно-червоно-хресна служба в Галицькій державі...

${ }^{11}$ Олійник О. Діяльність Українського Червоного Хреста у Східній Галичині в період ЗУНР... С. 57-60.

${ }^{12}$ Кравець А. Медики у визвольних змаганнях українського народу... С. 30.

${ }^{13}$ Олійник О. Діяльність Українського Червоного Хреста у Східній Галичині в період ЗУНР... С. 57-60.

${ }^{14}$ Рижій I. Санітарна Служба в Листопадових Днях у Львові. Bicmi комбатанта. URL: http://komb-aingwar.blogspot.com/2009/01/blog-post_13.html?m=1.

${ }_{15}^{15}$ Кравець А. Медики у визвольних змаганнях українського народу... С. 25.

${ }^{16}$ Олійник О. Діяльність Українського Червоного Хреста у Східній Галичині в період ЗУНР... С. 57-60.
} 
Вся червонохресна служба розподілялася на: а) першодопомогову службу (перев'язково-лікарську) при фронтовій смузі чи при державному кордоні; б) при транспортовій службі, тобто під час перевезення військових частин на або із фронтових смуг; в) у міських осередках при міських шпиталях.

Першим головою Галицького Українського Червоного Хреста був О. Гордієвський. 20 листопада 1918 р. Червоний Хрест реорганізовано в напівдержавну організацію із відділами по найважливіших містах. Ї̈ї головою призначений Остап Прийма ${ }^{17}$. Несподіваний відступ 3 м. Львова та свідомий саботаж з боку поляків-залізничників не дали можливості евакуювати санітарне майно, що згодом негативно вплинуло на роботу санітарної служби ${ }^{18} \mathrm{i}$, у свою чергу, ускладнило діяльність Червоного Хреста.

Після акту об'єднання ЗУНР із УНР в січні 1919 р. Галицький Український Червоний Хрест підпорядковувався Всеукраїнському Товариству Українського Червоного Хреста ${ }^{19}$. 27 лютого 1919 р. на I Загальних зборах Українського Червоного Хреста в м. Станиславові в присутності значної кількості містян було прийнято рішення про заснування в Західній області УНР (далі ЗОУНР) відділу Українського (Київського) Червоного Хреста, організацію якого було доручено очолити О. Приймі. На зборах вибрано членів управи та затверджено поділ на чотири секції ${ }^{20}$.

Одним із головних завдань, що поставило керівництво української держави перед Червоним Хрестом у Східній Галичині, була закупівля ліків та медичного інвентаря. Нагальне вирішення цього питання було зумовлене ще й тим, що Перша світова війна, розпад Австро-Угорської імперії, польсько-українська збройна боротьба зруйнували традиційні шляхи постачання ліків і дезінфекційних засобів до Галичини, тому постійно відчувався їхній брак ${ }^{21}$. Крім того, в умовах тотальної блокади Східної Галичини ворожими країнами, не вистачало карантинних бараків та кваліфікованого медичного персоналу ${ }^{22}$. У таких умовах закупівлю медикаментів здійснювала Місія Українського Червоного Хреста у м. Берлін під орудою Костя Воєвідки та його помічника сотника Луговенка. Завдання Місії полягало у придбанні для українських збройних сил медичного устаткування, медикаментів, одягу, білизни, постелі. Ліки купували на фармацевтичних фабриках Німеччини чи Швейцарії. Надавалася вагома підтримка 3 боку Наддніпрянської України. Так, кошти на закупівлю ліків були використані з рахунків, які відкрив в берлінських банках уряд гетьмана П. Скоропадського, а пізніше - уряд УНР ${ }^{23}$. На боротьбу з пошестями в ЗОУНР навесні 1919 р. керівництво УНР асигнувало кошти на 3 млн гривень $^{24}$. Окрім цього, в березні 1919 р. на території Східної Галичини у м. Броди свій осідок створила санітарно-червонохрестна служба з Наддніпрянщини. Таким чином, перебуваючи в районі відносно віддаленому від бойових дій санітарно-червонохресна управа УНР змогла реорганізуватися. Але через продовження боїв на польсько-українському фронті, медично-аптечне майно ЗОУНР не могло бути прикріплене до медичної управи наддніпрянського уряду ${ }^{25}$.

Окрім співпраці з УНР були також і спроби вирішити проблему забезпечення Червоного Хреста й іншими шляхами. Так, у лютому 1919 р. $з$ метою закупівлі медикаментів, дезінфекцій-

\footnotetext{
${ }^{17}$ Трембіцький В. Санітарно-медична справа в Україні. Санітарно-червоно-хресна служба в Галицькій державі...

${ }^{18}$ Кравець А. Медики у визвольних змаганнях українського народу... С. 32.

${ }^{19}$ Трембіцький В. Санітарно-медична справа в Україні. Санітарно-червоно-хресна служба в Галицькій державі...

20 Загальні збори "Укр. Червоного Хреста". Република. 1919. 8 березня. Ч. 30. С. 1.

${ }^{21}$ Давибіда Л. Боротьба з інфекційними захворюваннями в Західно-Українській Народній Республіці... C. $182-187$.

${ }_{22}^{22}$ Кравець А. Медики у визвольних змаганнях українського народу... С. 25.

${ }^{23}$ Рутар В. Є. Діяльність керівництва ЗУНР по організації закордонних поставок військового майна для Галицької Армії. Гуманітарний журнал. 2011. № 3-4. C. 216-225. URL: http://gj.nmu.org.ua/pdf/2011/34/Rutar.pdf.

${ }^{24}$ Давибіда Л. Боротьба з інфекційними захворюваннями в Західно-Українській Народній Республіці... С. $182-187$.

25 Лікарський світ за Української Держави за Директорії УНР (1919-1920). Вісті комбатанта. 2013. 20 жовтня. URL: https://komb-a-ingwar.blogspot.com/2013/10/1919-1920.html?m=1 .
} 
них засобів та вербування санітарного персоналу до Австрії вирушив граф Тун-Гогенштайн, який зголосився на службу при Українськім Червонім Хресті. Проте зі сторони української влади він особливою довірою не користувався, оскільки мав славу авантюриста. Ці підозри підтвердилися, коли у травні 1919 р. 3 м. Відня до м. Станиславова надійшли перші чотири вагони гуманітарної допомоги, виділених Червоним Хрестом за посередництва графа Туна. Після того, як вагони були відчинені, то виявилося, що чимало одягу, шкіри і ниток зіпсовані, а медикаментів та дезінфекційних засобів взагалі не було ${ }^{26}$. Лікарському персоналу, що прибув 3 м. Відня на Покуття для боротьби з епідемією висипного тифу, бракувало відповідної кваліфікації, а в переважній більшості це були аферисти, які не мали жодного відношення до медицини і намагалися обманом здобути собі кошти.

Велися переговори 3 австрійським товариством Червоного Хреста. Міжнародна організація Червоного Хреста в березні 1919 р. виділила на закупівлю медикаментів для Галичини 1 млн крон ${ }^{27}$.

Міжнародний Червоний Хрест розгорнув свою діяльність на території Східної Галичини. Зокрема, газета "Република" від 16 березня 1919 р. повідомляла, що “в Станиславові перебуває від вівтірка швайцарська місія Червоного Хреста під проводом д-ра Фріка. Місія має завдання переговорювати в справі виміни і транспорту полонених в Росії та Української Народньої Республіки. Крім того, простудіює вона санітарні відносини і запотребовання санітарних матеріялів в західній области Укр. Нар. Республіки. Вчора оглянув Др. Фрік в товаристві штабового лікаря д-ра Біласа станиславівські військові лічниці, а сьогодні в товаристві санітарного шефа Дра Курівця лічниці для цивільної людности. Сьогодні передполуднем прийняв Дра Фріка на авдієнції президент секретаріяту Др Голубович. Після того відбулася конференція між Дром Фріком і держ. секретарем внутр. справ Дром Макухом і санітарним шефом Дром Курівцем" $"$.

В особливо небезпечних з точки зору охорони здоров'я місцевостях Східної Галичини на кошти Міжнародного Червоного Хреста організовувався сталий медичний нагляд та харчування незаможного населення. Такий догляд здійснено 22 березня 1919 р. у с. Ямниця Станиславівського повіту. Тут містилася польова кухня для хворих на тиф місцевих мешканців ${ }^{29}$.

Будучи визнаним тільки де факто, а не де юре Український Червоний Хрест користувався обмеженою допомогою від Міжнародного Червоного Хреста. Українське товариство могло мати контакти з іншими членами організації, але немало права голосу при прийнятті міжнародних рішень ${ }^{30}$.

За таких обставин досить вагому підтримку своєї діяльності Український Червоний Хрест в ЗУНР отримав від місцевих жителів. Зазвичай, благодійна активність населення Східної Галичини проявлялась у внесенні грошових пожертв на користь даної організації. Так, станом на 1 квітня 1919 р. відділ Червоного Хреста у м. Станиславові отримав 73921 корону пожертв ${ }^{31}$. За квітень організація зібрала 27327 корон членських внесків та пожертв ${ }^{32}$. Тільки селяни з околиць м. Чорткова в березні 1919 р. передали для Червоного Хреста 2000 корон $^{33}$.

\footnotetext{
${ }^{26}$ Давибіда Л. І. Розвиток системи охорони здоров'я в Галичині: історичний аспект (1918-1939рр.) : дис. ... канд. іст. наук. Івано-Франківськ, 2015. С. 81.

27 Давибіда Л., Королько А. Санітарно-епідемічна ситуація на Покутті у роки національно-визвольних змагань західних українців 1918-1919 рр. Питання історії України. 2013. Т. 16. С. 62-67. URL: http://nbuv.gov.ua/UJRN/Piu_2013_16_15.

${ }_{28}^{28}$ Швайцарська місія Червоного Хреста у Станіславові. Република. 1919. 16 березня. Ч. 37. С. 3-4.

29 Давибіда Л. І. Розвиток системи охорони здоров’я в Галичині: історичний аспект (1918-1939рр.).. C. 80.

${ }^{30}$ Трембіцький В. Українська санітарно-допомогова праця на міжнародному грунті. Вісті комбатанта.

2015. 16 березня. URL: http://komb-a-ingwar.blogspot.com/2015/03/blog-post_16.html?m=1.

${ }^{31}$ Жертви на Українське Товариство Черв. Хреста (Відділ в Станіславові) Република. 1919. 1 квітня Ч. 50. C. 3.

${ }^{32}$ На Укр. Червоний Хрест. Република. 1919. 8 травня. Ч. 79. С. 4.

33 Для оборонців рідного краю. Жертволюбивість чортківських селян. Република. 1919. 21 березня. Ч. 41. C. 2.
} 
Широкого поширення збір коштів на Український Червоний Хрест набув серед населення Галицької Гуцульщини. Зокрема, у другій половині лютого 1919 р. Василь Крицкалюк зі с. Смодного Косівського повіту зібрав 17 корон, а смоднянський єврей Гуго Блязенштайн пожертвував 20 злотих. Жителі м. Старих Кут зібрали для Косівського комітету Українського Червоного Хреста 1234 корони і два вози харчів.

На потреби Українського Червоного Хреста громада с. Космач Косівського повіту внесла 134 корони. Дещо пізніше начальник громади Петро Сіреджук і секретар Казимир Ніньовський зібрали ще 855 корон. У с. Середній Березів місцеві жителі зібрали 254 корони, а віруючі під час богослужіння в церкві с. Великий Ключів Печеніжинського повіту - 265 корон. Достатньо великий внесок - 1765 корон - на Український Червоний Хрест зробила громада с. Москалівки Косівського повіту.

Для Українського Червоного Хреста гуцули теж вносили пожертвування окремо від своїх громад. Так, для Українського Червоного Хреста Петро Строїч з с. Рожнів Снятинського повіту (тепер село Косівського району Івано-Франківської обл.) у березні 1919 р. пожертвував 10 корон $^{34}$.

Частими були також і пожертви з прибутків отриманих від концертів та інших культурних заходів, що проводились на території Східної Галичини. Так, Модест Левицький передав на користь Червоного Хреста 2063 корони прибутку від концерту організованого в м. Станиславів 19 березня 1919 p. ${ }^{35} .31$ березня 1919 р. на вечорі в честь Тараса Шевченка, що відбувся в с. Бороні біля м. Турки було зібрано 2671 корону для організації ${ }^{36}$. Аматори художньої самодіяльності с. Яблунова Косівського повіту 1 березня 1919 р. дали концерт з нагоди злуки двох частин України. Дохід від концерту в сумі 1400 корон і добровільні пожертви в сумі 502 корони віддано у фонд Українського Червоного Хреста. На Український Червоний Хрест 3 концерту в м. Косові здано 831 корону ${ }^{37}$. Культурно-освітнє товариство акторів "Новий львівський театр" у свою чергу давало безкоштовні вистави для воїнів УГА, на користь Українського Червоного Хреста тощо. На потреби Українського Червоного Хреста також передано дохід від концерту Української республіканської капели (11 квітня 1919 р.) в м. Станиславів ${ }^{38}$.

Окрім українського населення підтримку Українському (Галицькому) Червоному Хресту в його діяльності надавали і представники місцевої єврейської спільноти. Так, до прикладу, комендант м. Ходорів Д. Мазуренок отримав від представників Єврейської Національної Ради міста зібрані на користь Червоного Хреста 2000 корон $^{39}$.

Доволі масовою була участь українських жінок краю в гуманітарних організаціях, зокрема і в Українському Червоному Хресті ${ }^{40}$. Жіночі організації активно збирали кошти на потреби Червоного Хреста. Зокрема, Товариство Українських Жінок 6 березня 1919 р. організувало 3 цією метою благодійний концерт. Таким чином, було отримано 4267 корон $^{41}$. Вагома роль в організації гуманітарних акцій належала жінкам-монахиням. Зокрема, в одному з військових госпіталів УГА пораненими опікувалися сестри-служебниці ${ }^{42}$.

\footnotetext{
${ }^{34}$ Сіреджук П. Суспільно-політичний рух і культурне життя галицької Гуцульщини періоду ЗУНР. Галичина. 2012. Ч. 20-21. С. 192-197.

${ }^{35}$ На Укр. Червоний Хрест... С. 4.

${ }^{36}$ Новинки. Вечір в честь Тараса Шевченка. Република. 1919. 1 травня. Ч. 74. С. 3.

${ }^{37}$ Сіреджук П. Суспільно-політичний рух і культурне життя галицької Гуцульщини періоду ЗУНР... С. 192-197.

${ }^{38}$ Бурдуланюк В. Театр в умовах національно-визвольної боротьби галицьких українців початку ХХ століття. Галичина. 2014. Ч. 25-26. С. 364-367.

39 Жертви на Червоний Хрест. Република. 1919. 16 квітня. Ч. 63. С. 4.

${ }^{40}$ Сапіга О. П. Кадрове забезпечення медичної та санітарної служби УГА в 1918-1920 рр. Військовонауковий вісник. Академія сухопутних військ. Вип. 14. Львів, 2011. С. 93-107.

${ }^{41}$ Оповістки. Република. 1919. 1 березня. Ч. 24. С. 4.; На Укр. Червоний Хрест. Република. 1919. 8 травня. Ч. 79. С. 4.

${ }^{42}$ Сапіга О. П. Кадрове забезпечення медичної та санітарної служби УГА в 1918-1920 рр... С. 93-107.
} 
В Червоному Хресті, крім українок, працювали й жінки інших національностей. Так, Андрій Назар згадував: "В другій половині січня 1919 р. прибули до нашої лічниці (V Сокальської Бригади. - O. О.) дві доглядачки німки, сестри Черв.Хреста...”43.

Завдяки активній підтримці українського населення в різних містах і селах Східної Галичини функціонували госпіталі Червоного Хреста. Зокрема, для організації успішної роботи 3 потерпілими солдатами функціонувало відділення українського товариства "Червоний хрест" у м. Коломия ${ }^{44}$, та лічниці під його патронатом у м. Чортків, с. Паликорови ${ }^{45}$ і протиепідемічний шпиталь у м. Дрогобич ${ }^{46}$.

Під час польсько-української війни Галицький Червоний Хрест, окрім надавання медичної та санітарно-епідемічної допомоги, організовував на території Східної Галичини низку інших заходів серед мирного населення та військових. Організація намагалась налагодити зв'язки між населенням ЗОУНР та їхніми родичами на захоплених поляками теренах. Так, делегація Українського Червоного Хреста із м. Львів. (Д. Старосольська, О. Косевич і С. Олеськів), яка об'їздила в Західній Галичині табори інтернованих українців, перебуваючи в м. Станиславові передала до редакції газети "Република" листи зі м. Львова ${ }^{47}$. При отримані цих листів адресатами в редакції газети було зібрано 65 корон для Червоного Хреста ${ }^{48}$. Місцеві червонохресні організації за сприяння населення здійснювали збір та доставку на фронт подарунків для солдатів до Великодніх свят. Так, 18 квітня 1919 р. з Гусятинщини на лінію фронту вирушила повітова делегація Червоного Хреста у складі трьох осіб. Перед ії від’їздом по селах було зібрано: “400 великих пасок, 209 кіп сирих яєць і чимало гроша, за що закуплено 192 фунта тютюну, 1000 пачок сірників, ... 6 вепрів, з яких нароблено силу ковбас і вудженки"

У зв'язку з безперервними військовими діями, медичні і санітарні установи (в тому числі й Український Галицький Червоний Хрест) значно менше уваги приділяли санітарному та гуманітарному забезпеченню мирного населення Східної Галичини ${ }^{50}$.

В умовах війни ще одною важливою ділянкою роботи Червоного Хреста стало забезпечення опіки над полоненими польськими військовими. Степан Олеськів у праці "Причинки до історії Українського Червоного Хреста на 3.У.3.” зазначав: “Праці усіх філій йшли по вказівкам “Зарядження державного Секретаріяту внутрішних і військових справ, видане 16 лютого 1919 в порозумінню з причасними Державними Секретаріатами в справі виконання умови заключеної дня 2 лютого 1919 р. ${ }^{51}$ у Львові між українсько-польською воюючою стороною, що до усталення засад обопільного трактування ранених, полонених та інтернованих". Він вказував, що “...Делегації Українського Червоного Хреста звиджували табори польських полонених, несли поміч інтернованим і полоненим українцям в Польщі...” С. Олеськів вказував на

\footnotetext{
${ }^{43}$ Назар А. Сторінка до історії V Сокальської Бригади. Полева лічниця в Сокалі. Літопис Червоної Калини. Львів, 1938. Грудень. С. 5. URL: http://avr.org.ua/index.php/viewDoc/11697/.

${ }^{44}$ Королько. А. Українські повітові ради Покуття періоду ЗУНР: структура і практична діяльність (листопад 1918 р. - травень 1919 р.). Галичина. 2014. Ч. 25-26. С. 91-113.

45 Давибіда Л. Боротьба з інфекційними захворюваннями в Західно-Українській Народній Республіці ... C. $182-187$.

${ }^{46}$ Сапіга О. Організація військових госпіталів Української Галицької Армії та їх матеріальне забезпечення (1918-1920рр.). Наукові записки Тернопільського наиіонального педагогічного університету ім. Володимира Гнатюка. Серія : Історія / за заг. ред. проф. І. С. Зуляка ; редкол.: М. Алексієвець, Л. Алексієвець, М. Бармак [та ін.]. Тернопіль : Вид-во ТНПУ ім. В. Гнатюка, 2010. Вип. 2. С. 79-85.

${ }^{47}$ Новинки. Дєлегація Українського Червоного Хреста із Львова. Република. 1919. 22 лютого. Ч. 18. С. 4; Богачевська-Хом'як М. Білим по білому: жінки в громадському житті України. 1884-1939. Київ : Либідь, 1995. C. 195.

${ }^{48}$ Жертви на Червоний Хрест. Република. 1919. 4 березня. Ч. 26. С. 4.

${ }^{49}$ Роздача свят. дарунків на фронті. Република. 1919. 29 квітня. Ч. 72. С. 2-3.

50 Давибіда Л., Королько А. Санітарно-епідемічна ситуація на Покутті у роки національно-визвольних змагань західних українців 1918-1919 рр. Питання історії України. 2013. Т. 16. С. 62-67. URL: http://nbuv.gov.ua/UJRN/Piu_2013_16_15.

51 Польсько-українська умова від 1-го лютого 1919 р. Вicmi комбатанта. 2008. 9 листопада. URL: https://komb-a-ingwar.blogspot.com/2008/11/1-1919.html?m=1.
} 
80

можливість доступу в шпиталях до польських полонених римо-католицьких сестер-монахинь і священиків та дозволу на листування ${ }^{52}$.

Здійснювалися спроби налагодження співпраці між українським і польським товариствами Червоного Хреста. Так, вищезгадана поїздка по таборах Західної Галичини Д. Старосольської, О. Косевич і С. Олеськів була частиною польсько-українських домовленостей, згідно яких по три представники воюючих сторін під егідою Червоного Хреста мали відвідати табори полонени ${ }^{53}$. У свою чергу, делегація Польського Червоного Хреста відвідала табори полонених та інтернованих поляків на території ЗОУНР. Часопис "Покутський вісник" повідомляв: "Відділ польського "Червоного Хреста" оглянув на днях у своїм переїзді тутешні шпиталі та табор інтернованих Поляків (на Косачеві в м. Коломиї. - O. О.). Польські висланці передали своїм землякам гроші та провірені цензурою письма. У всіх шпиталях і таборі висланці ствердили людяність поведення 3 бранцями та взірцевий лад"54. Крім червонохресних організацій потреби полонених та інтернованих у даному таборі намагався забезпечувати "Комітет опіки польських жінок над військовополоненими та інтернованими особами", який був створений у листопаді 1918 p. ${ }^{55}$.

Отже, слід виокремити такі головні фактори в організації санітарно-епідемічної та гуманітарної діяльності Червоного Хреста в Східній Галичині періоду ЗУНР: тривалі бойові дії періоду Першої світової війни, польсько-українська війна 1918-1919 рр. та ізоляція краю від традиційних шляхів отримання ліків і медичного інвентаря, складні умови праці, зумовлені воєнними діями, негативно відбивались на результатах роботи як Українського, так і Міжнародного Червоного Хреста. Проте, з іншого боку, впродовж свого функціонування на території Східної Галичини, окрім співпраці з міжнародним червонохресним рухом, українська організація у різних формах отримувала активну підтримку від уряду УНР та місцевого населення. Установа постійно стикалася із нестачею коштів, ліків та браком кваліфікованого медичного персоналу, не могла в повній мірі надавати допомогу військовим та цивільним жителям. Однак співпраця з іншими червонохресними організаціями зумовила певне пом'якшення негативних наслідків санітарно-епідемічного та гуманітарного становища у Східній Галичині доби ЗУНР.

\title{
SANITARY-EPIDEMIC AND HUMANITARIAN ACTIVITY OF THE RED CROSS IN EASTERN GALICIA DURING THE WUPR IN THE CONTEXT OF THE CHARITABLE ACTIVITY OF THE LOCAL POPULATION
}

\author{
Oleg OLIYNYK \\ State Higher Educational Institution \\ "Vasyl Stefanyk Precarpathian National University", \\ Department of World History, \\ Shevchenko St., 57, 76018, Ivano-Frankivsk, Ukraine \\ e-mail:oleg93hist@meta.ua
}

\section{Summary}

The purpose of the work is to carry out a comprehensive and objective coverage of the sanitaryepidemic and humanitarian activities of the red-cross organizations in the territory of Eastern Galicia during the WUPR and their interaction with the public in the process of work of the partnership in the above-mentioned directions. To analyze the effectiveness of this organization's activities to address the medical and humanitarian needs of the military and civilian population of the identified region.

\footnotetext{
${ }^{52}$ Олеськів С. Причинки до історії Українського Червоного Хреста на 3.У.3. Літопис Червоної Калини. Львів, 1934. Червень. С. 5-6. URL: http://avr.org.ua/index.php/viewDoc/11646/.

${ }_{53}^{53}$ Богачевська-Хом'як М. Білим по білому: жінки в громадському житті України... С. 193.

${ }_{54}^{54}$ Життя Покуття. Відділ польського “Червоного Хреста”. Покутський вісник. 1919. 2 лютого. Ч. 9. С. 3.

${ }_{55}^{55}$ Гаврилишин П., Чорненький Р. Діяльність Комітету опіки польських жінок над військовополоненими та інтернованими особами у Коломиї в період польсько-української війни 1918-1919 рр. Коломия, Покуття і Гуиульщина в II Речі Посполитій. Вибрані питання : збірник наукових праць. Варшава, 2017. C. 32-46.
} 
The methodological basis of the study is the general scientific principles of objectivity, comprehensiveness and historicism. The problem-chronological, logical and comparative methods are used in the work.

The organizational structure and sanitary-epidemic and humanitarian activity of the Ukrainian Red Cross on the territory of Galicia are analyzed. The historical conditions in which this organization worked was considered. In particular, the medical and humanitarian situation caused by the prolonged military actions of the period of the First World War and the growing Polish-Ukrainian conflict that characterized the need for the creation and organization of the Ukrainian Red Cross was described. The attitude and participation in the organization of representatives of the medical community of Eastern Galicia of different nationalities is analyzed. The work of foreign missions of the red-colored structures on the territory of the region and their interaction with local authorities is highlighted. The process of interaction between the Polish and Ukrainian Red Cross Societies in solving the problem of custody of prisoners and interned soldiers in the process of moving civilians through the front line is considered. Characterized influence and scale of charitable activity of local Ukrainian and Jewish population on the work of the Ukrainian Red Cross. Considered activities of the Red Cross in Eastern Galicia during the ZUNR was an important factor that reduced the negative impact of the complex sanitary-epidemic and humanitarian situation that resulted from bloody hostilities during the First World War and the Polish-Ukrainian confrontation on the territory of the region.

Keywords: Red Cross, East Galicia, ZUNR, charitable activity.

\section{REFERENCES}

Bohachevska-Khomiak M. Bilym po bilomu : zhinky v hromadskomu zhytti Ukrainy. 1884-1939. Kyiv : Lybid, 1995. 424 s. [in Ukrainian].

Burdulaniuk V. Teatr $\mathrm{v}$ umovakh natsionalno-vyzvolnoi borotby halytskykh ukraintsiv pochatku XX stolittia. Halychyna. 2014. Ch. 25--26. S. 364-367. [in Ukrainian].

Havrylyshyn P., Chornenkyi R. Diialnist Komitetu opiky polskykh zhinok nad viiskovopolonenymy ta internovanymy osobamy u Kolomyi v period polsko-ukrainskoi viiny 1918-1919 rr. Kolomyia, Pokuttia $i$ Hutsulshchyna v II Rechi Pospolytii. Vybrani pytannia: zbirnyk naukovykh prats. Varshava, 2017. S. 32-46. [in Ukrainian].

Davybida L. Borotba z infektsiinymy zakhvoriuvanniamy v Zakhidno-Ukrainskii Narodnii Respublitsi. Halychyna. 2014. Ch. 25-26. S. 182-187. [in Ukrainian].

Davybida L. I. Rozvytok systemy okhorony zdorovia v Halychyni: istorychnyi aspekt (1918-1939 rr.) : dys kand. ist. nauk. Ivano-Frankivsk, 2015. 262 s. [in Ukrainian].

Davybida L., Korolko A. Sanitarno-epidemichna sytuatsiia na Pokutti u roky natsionalno-vyzvolnykh zmahan zakhidnykh ukraintsiv 1918-1919 rr. Pytannia istorii Ukrainy. 2013. T. 16. S. 62-67. URL: http://nbuv.gov.ua/UJRN/Piu_2013_16_15. [in Ukrainian].

Dlia oborontsiv ridnoho kraiu. Zhertvoliubyvist chortkivskykh selian. Republika. 1919. 21 bereznia.

Ch. 41. S. 2. [in Ukrainian].

Zhertvy na Ukrainske Tovarystvo Cherv. Khresta (Viddil v Stanislavovi) Republika. 1919. 1 kvitnia

Ch. 50. S. 3. [in Ukrainian].

Zhertvy na Chervonyi Khrest. Republika. 1919. 16 kvitnia. Ch. 63. S. 4. (in Ukr.ainian).

Zhertvy na Chervonyi Khrest. Republika. 1919. 4 bereznia. Ch. 26. S. 4. [in Ukrainian].

Zhyttia Pokuttia. Viddil polskoho "Chervonoho Khresta". Pokutskyi visnyk. 1919. 2 liutoho. Ch. 9. S. 3.

Zahalni zbory "Ukr. Chervonoho Khresta". Republika. 1919. 8 bereznia. Ch. 30. S. 1. [in Ukrainian].

Korolko. A. Ukrainski povitovi rady Pokuttia periodu ZUNR: struktura i praktychna diialnist (lystopad

1918 r. - traven 1919 r.). Halychyna. 2014. Ch. 25-26. S. 91-113. [in Ukrainian].

Kravets A. Medyky u vyzvolnykh zmahanniakh ukrainskoho narodu : (vid Ukrainskoho Chervonoho

Khresta do Sluzhby Zdorovia UPA). Lviv : Halytska vydavnycha spilka, 2010. 178 s. [in Ukrainian].

Likarskyi svit za Ukrainskoi Derzhavy za Dyrektorii UNR (1919-1920). Visti kombatanta. 2013.

20 zhovtnia. URL: https://komb-a-ingwar.blogspot.com/2013/10/1919-1920.html?m=1. [in Ukrainian].

Na Ukr. Chervonyi Khrest. Republika. 1919. 8 travnia. Ch. 79. S. 4. [in Ukrainian].

Nazar A. Storinka do istorii V Sokalskoi Bryhady. Poleva lichnytsia v Sokali. Litopys Chervonoi

Kalyny. Lviv, 1938. Hruden. S. 5. URL: http://avr.org.ua/index.php/viewDoc/11697/. [in Ukrainian].

Novynky. Vechir v chest Tarasa Shevchenka. Republika. 1919. 1 travnia. Ch. 74. S. 3. [in Ukrainian].

Novynky. Dielehatsiia Ukrainskoho Chervonoho Khresta iz Lvova. Republika. 1919. 22 liutoho. Ch. 18.

S. 4. [in Ukrainian].

Oleskiv S. Prychynky do istorii Ukrainskoho Chervonoho Khresta na Z.U.Z. Litopys Chervonoi Kalyny.

Lviv, 1934. Cherven. S. 5-6. URL: http://avr.org.ua/index.php/viewDoc/11646/. [in Ukrainian]. 


\section{2}

Oliinyk O. Diialnist Ukrainskoho Chervonoho Khresta u Skhidnii Halychyni v period ZUNR. Ukraina u svitovomu istorychnomu prostori : zb. materialiv Vseukr. nauk.-prakt. konf. m. Mariupol. 21 kvitnia 2017 r. I pid zah. red. K. V. Balabanova. Mariupol : MDU, 2017. S. 57-60. [in Ukrainian].

Opovistky. Republika. 1919. 1 bereznia. Ch. 24. S. 4. [in Ukrainian].

Polsko-ukrainska umova vid 1-ho liutoho 1919 r. Visti kombatanta. 2008. 9 lystopada. URL: https://komb-a-ingwar.blogspot.com/2008/11/1-1919.html?m=1. [in Ukrainian].

Ryzhii I. Sanitarna Sluzhba v Lystopadovykh Dniakh u Lvovi. Visti kombatanta. URL: http://komb-aingwar.blogspot.com/2009/01/blog-post_13.html?m=1. [in Ukrainian].

Rozdacha sviat. darunkiv na fronti. Republika. 1919. 29 kvitnia. Ch. 72. S. 2-3. [in Ukrainian].

Rutar V. Ye. Diialnist kerivnytstva ZUNR po orhanizatsii zakordonnykh postavok viiskovoho maina dlia Halytskoi Armii. Humanitarnyi zhurnal. 2011. № 3-4. S. 216-225. URL: http://gj.nmu.org.ua/pdf/2011/34/Rutar.pdf. [in Ukrainian].

Rutar V. Ye. Mobilizatsiine i materialno-tekhnichne zabezpechennia Halytskoi armii v period ukrainsko-polskoi viiny 1918-1919 rr. (za materialamy povitovoi presy ZUNR). Viiskovo-naukovyi visnyk. 2010. Vyp. 14. S. 79-92. URL: http://nbuv.gov.ua/UJRN/vnv_2010_14_7. [in Ukrainian].

Sapiha O. Orhanizatsiia viiskovykh hospitaliv Ukrainskoi Halytskoi Armii ta yikh materialne zabezpechennia (1918-1920 rr.). Naukovi zapysky Ternopilskoho natsionalnoho pedahohichnoho universytetu im. Volodymyra Hnatiuka. Seria : Istoriia / za zah. red. prof. I. S. Zuliaka ; redkol.: M. Aleksiievets, L. Aleksiievets, M. Barmak [ta in.]. Ternopil : Vyd vo TNPU im. V. Hnatiuka. 2010. Vyp. 2. S. 79-85. [in Ukrainian].

Sapiha O. P. Kadrove zabezpechennia medychnoi ta sanitarnoi sluzhby UHA v 1918-1920 rr. Viiskovonaukovyi visnyk. Akademiia sukhoputnykh viisk. Vyp. 14. Lviv, 2011. S. 93-107. [in Ukrainian].

Siredzhuk P. Suspilno-politychnyi rukh i kulturne zhyttia halytskoi Hutsulshchyny periodu ZUNR. Halychyna. 2012. Ch. 20-21. S. 192-197. [in Ukrainian].

Trembitskyi V. Sanitarno-medychna sprava v Ukraini. Sanitarno-chervono-khresna sluzhba v Halytskii derzhavi. Visti kombatanta. 2016. 27 bereznia. URL: http://komb-a-ingwar.blogspot.com/2016/03/blogpost_27.html?m=1. [in Ukrainian].

Trembitskyi V. Ukrainska sanitarno-dopomohova pratsia na mizhnarodnomu hrunti. Visti kombatanta. 2015. 16 bereznia. URL: http://komb-a-ingwar.blogspot.com/2015/03/blog-post_16.html?m=1. [in Ukrainian].

Shvaitsarska misiia Chervonoho Khresta u Stanislavovi. Republika. 1919. 16 bereznia. Ch. 37. S. 3-4. [in Ukrainian]. 